DANDELION

postgraduate arts journal \& research network

VOLUME 6 NUMBER I AUTUMN 2015
Connie Gallagher is a young artist and curator living and working in London. She has curated and exhibited in solo and group exhibitions across London. She has also been a guest speaker at various talks for Central Saint Martin's, East Street Arts, and finally the 'Visual Artists Today' symposium that was held in May 2015 at Peltz Gallery, School of Arts, Birkbeck.

\title{
Occupational Realism: Reflecting on the Relationship Between my Workaday Job and Artistic Labour
}

\author{
Connie Gallagher
}

On 19 May 2015 I gave a presentation at Arts Week for 'Visual Artists Today: a Symposium on the Artist Identity' at The Peltz Gallery, Birkbeck School of Arts, University of London. ${ }^{1}$ The talk was an extension of my research into the term 'occupational realism' ${ }^{2}$ which I had begun for a previous presentation I gave at the East Street Arts' Open Studio symposium, held at the Leeds City Art Gallery. ${ }^{3}$

Originating in the 1970s, occupational realism describes the practices of artists who have 'self-consciously inhabited their workaday jobs as art'. Learning about this term was a revelation; I realised that I had been unconsciously inhabiting my own 'workaday' job as part of my own art practice.

For the presentation at Birkbeck University, I interviewed artists who supported themselves financially through other jobs, asking them how they balanced their workaday job and artistic practice. I was interested to see whether they also considered these to be one and the same, in the same way that I now do. Whether working as a university fine-art tutor, gallery administrative assistant, ghost-painter, fine-art print technician, none would go as far as to describe their job as art, despite acknowledging that aspects of their jobs would often inform their work as an artist. What made my job so different, that I had come to do it as part of my practice? 
I have worked as a self-employed arts marketing promoter for the past four years. My job is flexible, fairly low skilled and within the arts. Whether I am handing out leaflets advertising upcoming exhibitions, or working front-ofhouse at museums and galleries collecting data, I have managed my job's hours around the time I need to put in as an artist/practitioner. This independence that I have felt, through being self-employed, has allowed me to continue my practice as an artist after graduating from university.

Over time I began to notice that the way I was working had changed, through regularly moving between locations and varying day-to-day shift times. As a result, my work space would move with me. I was working in coffee houses and setting up meetings in galleries where I was working; I had invariably come to use my job as part of my art practice. So, to include my workaday job into my artistic practice seemed a natural progression. I began to think of ways that I could include my job as a leafleter or data collector into my artwork; such as through commissioning myself to advertise an exhibition I was organising (as illustrated in Figure 1).

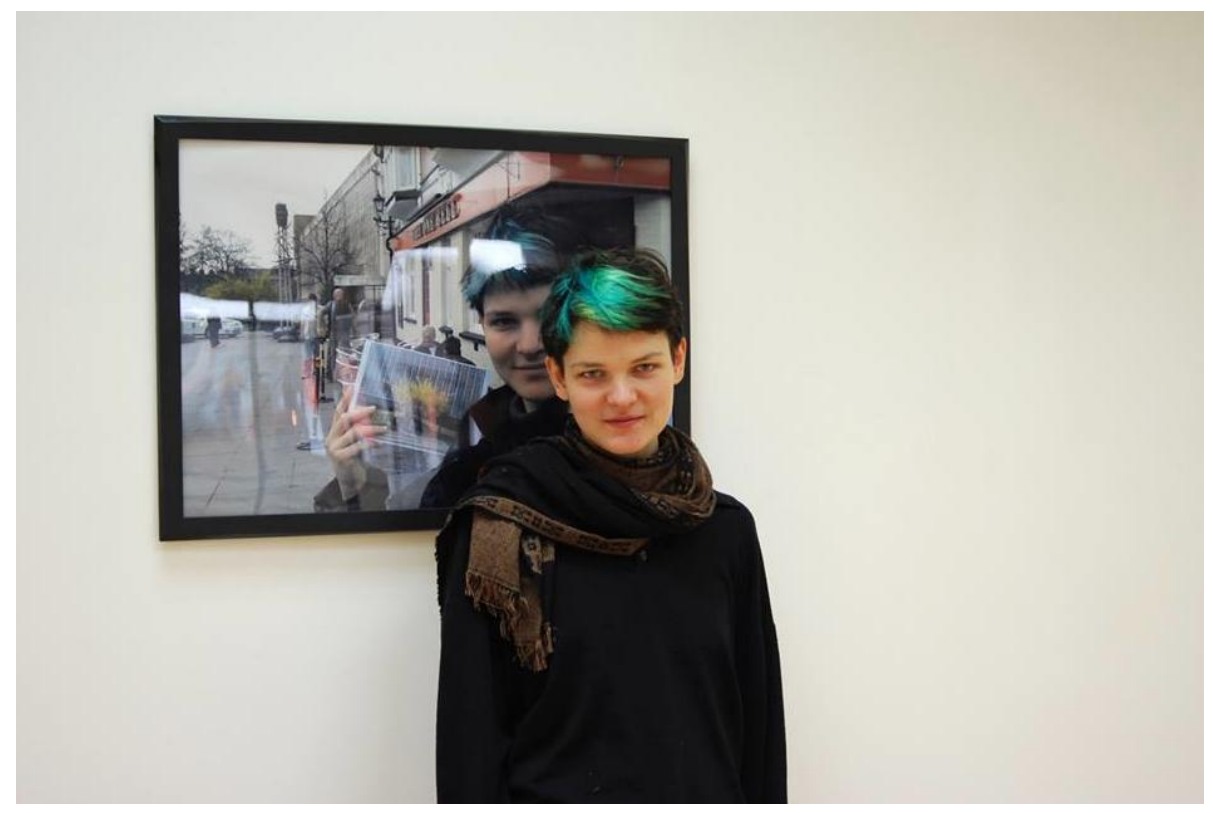

Figure 1. Missing You Already, 2014, digital print

For the exhibition Missing You Already, held in association with East St Arts at Charter Place, Watford, I commissioned Artshead, the arts marketing company I work for, to pay me to leaflet for the exhibition; as evidence that I completed the shift I am required to take a photo of myself at the location with the leaflet in hand. This is the photograph I presented in the final exhibition.

Would I describe my workaday job as art? The answer is both yes and no: no, it is not the final outcome of my creative activity as an artist; but also yes, it has provided me with a critical framework within which to position my labour as an 'arts marketing promoter' in the context of being an artist today. This context includes working in precarious jobs to sustain my career as an artist; which has led me to approach my job as a creative activity that can inform my artistic production - whether as the theme of an exhibition that I am curating, or as the material used for an art work. 


\section{Notes}

1 Further information on the symposium can be found at <http://www.scoop.it/t/artistidentity $>$.

2 Julia Bryan-Wilson, 'Occupational Realism', in Living Labor, ed. by Milena Hoegsberg \& Cora Fischer, (Berlin: Sternberg Press, 2013), pp. 99-125.

3 Further information on the East Street Arts symposium can be found at $<$ http://eaststreetarts.org.uk/archive/open-studios-symposium/>.

$4 \quad$ Julia Bryan-Wilson, 'Occupational Realism', TDR: The Drama Review, 56.4 (2012), pp. $32-48$

$5 \quad$ For more information on this exhibition please go to

< http://eaststreetarts.org.uk/uncategorized/missing-you-already/>.

\section{Works Cited}

Bryan-Wilson, Julia, 'Occupational Realism', in Living Labor, ed. by Milena

Hoegsberg \& Cora Fischer, (Berlin: Sternberg Press, 2013), pp. 99-125

'Occupational Realism', TDR: The Drama Review, 56.4 (2012), pp. 32-48 